\title{
EXCRETION PATTERN OF LABELLED SPERMATOZOA AND THE TIMING OF SPERMATOZOA FORMATION AND EPIDIDYMAL TRANSIT IN RABBITS INJECTED WITH THYMIDINE- ${ }^{3} \mathrm{H}^{*}$
}

\author{
R. P. AMANN, H. H. KOEFOED-JOHNSEN \\ AND H. LEVI
}

Dairy Breeding Research Center, The Pennsylvania State University, University Park, Pennsylvania; Sterility Research Institute, The Royal Veterinary and Agricultural College, Copenhagen; and Zoophysiological Laboratory A, University of Copenhagen

(Received 3rd November 1964, revised 12th April 1965)

Summary. Sixteen rabbits were injected with thymidine- ${ }^{3} \mathrm{H}$ and tissue sections or spermatozoa smears were evaluated by autoradiography. Two successive ejaculates were collected every second day. Analyses of labelled germ cells in twenty-four testes taken $1 \mathrm{hr}$ to 32 days postinjection showed that one cycle of the seminiferous epithelium required $10 \cdot 7 \pm 0.5$ days and that labelled spermatozoa should enter the caput epididymidis 31.4 days post-injection. Labelled spermatozoa were found in the proximal portion of four capita epididymidum 32 days and one caput 33 days post-injection, but not in eleven other capita epididymidum 28 to 31 days post-injection. Labelled spermatozoa first were detected in ejaculated semen from five rabbits on Days 38, 39, 41, 42 and 42. The mean number of grains/spermatozoon in autoradiograms of successive samples agreed closely with the scintillation count activity curve. However, neither curve represented the excretion pattern of spermatozoa labelled as preleptotene spermatocytes. The first samples containing labelled spermatozoa had a low percentage of highly labelled spermatozoa while, through mixing with spermatozoa labelled as spermatogonia, subsequent ejaculates contained up to $55 \%$ labelled spermatozoa but individual cell activity was lower. Labelled spermatozoa were excreted over a period of 2 to 3 weeks. Epididymal spermatozoa transit time averaged $9 \cdot 0$ days, but it ranged from $6 \cdot 6$ to $10 \cdot 6$ days even with a uniform semen collection schedule. Combined with autoradiographic evaluation of tissue sections or semen smears, intravenous injection of 0.1 to $0.3 \mathrm{mc} / \mathrm{kg}$ body weight of thymidine- ${ }^{3} \mathrm{H}$ should be adequate for experiments of this type.

* Authorized for publication on 20th October 1964 as Paper No. 2951 in the journal series of The Pennsylvania Agricultural Experiment Station. 


\section{INTRODUCTION}

Previous attempts to study epididymal transit and the excretion pattern of labelled spermatozoa have been hampered by several factors. Work with large animals has centred on ${ }^{32} \mathrm{P}$ injection (Koefoed-Johnsen, 1958; Ortavant, 1958; Orgebin-Crist, 1962). This precursor is nonspecific for spermatozoal-DNA and it is continuously, but in decreasing amounts, available for incorporation in spermatogonia and preleptotene spermatocytes. Thus, portions of the resulting data are difficult or impossible to interpret. The problem of precursor specificity can be overcome by use of adenine-8-14 $\mathrm{C}$ (Foote \& KoefoedJohnsen, 1959) or especially thymidine- ${ }^{3} \mathrm{H}$ (Sirlin, 1958; Hupp, Austin \& Murphree, 1961). Rubini, Cronkite, Bond \& Fliedner (1960) found that all nuclear labelling occurred in less than 60 min following thymidine- ${ }^{3} \mathrm{H}$ injection and that by $90 \mathrm{~min}$ all blood plasma activity was from tritiated water. A second problem is inherent in the generally used Geiger-Müller or scintillation measurements; they provide the mean radioactivity for a population of cells, but do not yield any estimate of the activity of an individual cell. As a result, it is impossible to differentiate between a low percentage of strongly labelled cells and a high percentage of weakly labelled cells in a semen sample. Thus, physiological interpretations based on these techniques may be incorrect. Autoradiography (ARG) of ${ }^{14} \mathrm{C}$ - or ${ }^{3} \mathrm{H}$-labelled spermatozoa enables evaluating the degree of labelling of a number of individual spermatozoa (Sirlin \& Edwards, 1958; Foote, 1959).

Cytological aspects of rabbit spermatogenesis recently were discussed by Swierstra \& Foote (1963). The present autoradiographic investigations provided information on the duration of spermatogenesis and the transit of spermatozoa through the epididymides as well as the labelling pattern of ejaculated spermatozoa after thymidine- ${ }^{3} \mathrm{H}$ injection.

\section{MATERIALS AND METHODS}

Sixteen young adult rabbits of mixed breeding (most were phenotypically New Zealand white), previously trained for semen collection by artificial vagina, were injected with thymidine-methyl- ${ }^{3} \mathbf{H}$ via the ear vein while under light ether anaesthesia. Two remained intact throughout the experimental period while the other fourteen were unilaterally castrated, killed or died between $1 \mathrm{hr}$ and 33 days post-injection (Table 1). In no case could death be attributed to radiation. To allow for stabilization of daily spermatozoa output and reserves of epididymal spermatozoa (Amann \& Almquist, 1962), semen collections were initiated at least 10 days prior to the time labelled spermatozoa were expected to enter the caput epididymidis. Two successive ejaculates, 10 to 20 min apart, were collected by artificial vagina from each rabbit every second day.

Immediately after semen collection, the gel plug, if present, was removed and the two individual ejaculates were weighed in their tared collection tubes. Ejaculate volume was assumed to equal ejaculate weight. After pooling the two ejaculates, spermatozoa concentration was determined by haemocytometer counts.

The ${ }^{3} \mathrm{H}$-activity of ejaculated spermatozoa was determined from Day 32 or 33 to at least Day 61. Ejaculated spermatozoa were centrifuged free of 
seminal plasma, washed three times with $6 \mathrm{ml}$ of $0.9 \% \mathrm{NaCl}$ and resuspended in $0.5 \mathrm{ml}$ of $1.0 \%$ sucrose solution. Duplicate smears were prepared on gelatinized glass slides for subsequent ARG. The remaining spermatozoa were suspended in $6 \mathrm{ml}$ saline, centrifuged down and resuspended in $\mathrm{N} \mathrm{NaOH}$ so that the total weight of spermatozoa and $\mathrm{NaOH}$ was $1.00 \mathrm{~g}$. The samples were hydrolysed $18 \mathrm{hr}$ in sealed tubes at $80^{\circ} \mathrm{C}$ and stored at $-20^{\circ} \mathrm{C}$ until assayed. Upon thawing, samples of hydrolysed spermatozoa (generally $250 \mu \mathrm{l}$ ) were neutralized with $\mathrm{HCl}$ and mixed with $13 \mathrm{ml}$ of NE-220 scintillation fluid in counting vials. Tritium activity was assayed in an Isotope Development Limited, Type

TABLE 1

INJECTED DOSE, BODY WEIGHT AND UTILIZATION OF RABBITS

\begin{tabular}{|c|c|c|c|c|}
\hline \multirow{2}{*}{$\begin{array}{c}\text { Thymidine- }{ }^{3} H \\
\quad \text { level } \\
(m c / k g)\end{array}$} & \multirow{2}{*}{ Rabbit } & \multirow{2}{*}{$\begin{array}{l}\text { Body } \\
\text { weight } \\
(\mathrm{kg})\end{array}$} & \multirow{2}{*}{$\begin{array}{l}\text { Days post- } \\
\text { injection semen } \\
\text { first collected }\end{array}$} & Utilization $\dagger$ \\
\hline & & & & Right side \\
\hline 0.5 & $\begin{array}{l}\mathrm{K}-60 \ddagger \\
\mathrm{K}-72 f \\
\mathrm{~K}-61 \ddagger\end{array}$ & $\begin{array}{l}3 \cdot 62 \\
3 \cdot 88 \\
3 \cdot 68\end{array}$ & $\begin{array}{l}21 \text { वा } \\
10\end{array}$ & $\begin{array}{c}\text { Sick (cold), killed Day } 32 \\
\text { Ejac. sperm. } \\
\text { Pasteurellosis, killed Day } 10\end{array}$ \\
\hline 0.8 & $\begin{array}{l}\mathrm{K}-83 \$ \\
\mathrm{~K}-84 \$ \\
\mathrm{~K}-85 \$\end{array}$ & $\begin{array}{l}2 \cdot 52 \\
2 \cdot 94 \\
2 \cdot 49\end{array}$ & $\begin{array}{l}22 \\
22 \\
22\end{array}$ & $\begin{array}{l}31 \\
1 \mathrm{hr} \\
32\end{array}$ \\
\hline $1 \cdot 0$ & $\begin{array}{l}\mathrm{K}-71 \ddagger \\
\mathrm{K}-70 \ddagger \\
\mathrm{K}-63 \ddagger\end{array}$ & $\begin{array}{l}3 \cdot 79 \\
3 \cdot 60 \\
3 \cdot 47\end{array}$ & $\begin{array}{l}229 \\
13 \\
17\end{array}$ & \begin{tabular}{cc}
\multicolumn{2}{c}{ Coccidiosis, died on Day 24} \\
Ejac. sperm. & 29 \\
28 & 30
\end{tabular} \\
\hline $1 \cdot 5$ & $\begin{array}{l}\mathrm{k}-64 \ddagger \\
\mathrm{k}-67 \ddagger \\
\mathrm{k}-66 \ddagger \\
\mathrm{k}-82 \$\end{array}$ & $\begin{array}{l}3 \cdot 28 \\
3 \cdot 17 \\
3 \cdot 49 \\
3 \cdot 10\end{array}$ & $\begin{array}{l}21 \pi \\
12 \\
18 \\
22\end{array}$ & $\begin{array}{cc}\text { Ejac. sperm. (remained intact) } \\
28 & \text { Ejac. sperm. } \\
30 & 29 \\
\text { Ejac. sperm. (remained intact) }\end{array}$ \\
\hline $2 \cdot 0$ & $\begin{array}{l}\mathbf{K}-62 \ddagger \\
\mathbf{K}-74 \ddagger \\
\mathbf{K}-75 \ddagger\end{array}$ & $\begin{array}{l}3 \cdot 30 \\
2 \cdot 49 \\
2 \cdot 49\end{array}$ & $\begin{array}{r}1 \\
17\end{array}$ & $\begin{array}{cc}4 \mathrm{hr} & 4 \mathrm{hr} \\
\text { Pasteurellosis, died on Day } 6 \\
\text { 3I }\end{array}$ \\
\hline
\end{tabular}

* Thereafter, two successive ejaculates were collected every other day.

$\dagger$ Number indicates the day after injection when castration or killing occurred, except where otherwise indicated.

† Thymidine-methyl-3H from New England Nuclear Corp., NET-27 lots 89-110-la to 89-110-le dated 14th September 1962 and with a specific activity of $100 \mathrm{mc} / \mathrm{mm}$; injected at $1.0 \mathrm{mc} / \mathrm{ml}$.

$\$$ Thymidine-methyl- ${ }^{3} \mathrm{H}$ from The Radiochemical Centre, Amersham, TRA-120 batch 5 dated 14th December 1962 and with a specific activity of $1520 \mathrm{mc} / \mathrm{mm}$; injected at $1.0 \mathrm{mc} / \mathrm{ml}$.

IT Two successive ejaculates also collected on Days 1, 5, 10, 15 and 20.

2022, coincidence liquid scintillation counter. Values were corrected for quenching using the internal standard procedure. Counts were made on duplicate or triplicate samples but, nevertheless, in some cases accuracy of the final values was questionable. This resulted from low numbers of spermatozoa in the hydrolysate in a few cases or more generally from electronic difficulty. For $\mathrm{k}-82$, spermatozoal activity was not determined by scintillation counting. To determine the biological half-life of ${ }^{3} \mathrm{H}$ circulating in the body water compartment, blood and/or seminal plasma also were assayed for $\mathrm{k}-60, \mathrm{k}-64$, K-70, K-71 and K-72. Blood plasma and seminal plasma were diluted 4:1 with 
$\mathrm{N} \mathrm{NaOH}$ and, after $18 \mathrm{hr}$ hydrolysis at $80^{\circ} \mathrm{C}$, samples of 50 or $100 \mu \mathrm{l}$ were counted in NE-220 scintillation fluid. High counts were obtained and these measurements appeared more reliable than those on spermatozoa.

At the time of castration or killing, tissues were fixed promptly in BouinHollande, dehydrated in ethanol, cleared in methyl benzoate followed by benzene and embedded in Tissuemat. Representative sections were cut at $5 \mu$ and affixed to gelatinized glass slides for ARG. For capita epididymidum representing Days 28 to 33 , sections were taken at $500 \mu$ intervals so that longitudinal sections representing eight to fifteen different levels were examined. This minimized the possibility that labelled spermatozoa might be missed.

The spermatozoal smear and tissue section slides were Feulgen-stained prior to ARG. Slides were dipped into Ilford $\mathrm{K}-5$ emulsion diluted $1: 1$ with glass distilled water, allowed to dry horizontally on a warm plate and placed in plastic slide boxes. Prior to sealing, the boxes were gassed, in a desiccator containing silica gel, with washed and dried $\mathrm{CO}_{2}$ produced by sublimation of Dry Ice. Storage during exposure, which varied from 14 to 45 days, was in a lead shield at $4^{\circ} \mathrm{C}$. Two exposure times were used for each set of slides. Exposed autoradiographs were developed in Amidol and, after fixation and washing, cover glasses were mounted with DPX. Background remained very low in all cases. All autoradiograms of smears or tissue from one rabbit were prepared at the same time.

The duration of the portion of spermatogenesis between injection and liberation of labelled spermatozoa into the caput epididymidis was determined in two ways: (a) evaluation of testicular autoradiograms representing various times after injection to ascertain the developmental progress of labelled germ cells and (b) examination of autoradiograms of capita epididymidum to find which day labelled spermatozoa entered. When labelled spermatozoa were found in the efferent ducts or region 2 of the caput epididymidis (Nicander, 1958), the percentage of labelled spermatozoa was determined on the basis of 500 to 1700 clearly identifiable, isolated cells. Spermatozoa examined included those in several tissue sections from each caput. In studies of the autoradiograms for eighteen ${ }^{3} \mathrm{H}$-free ejaculates, less than $1.5 \%$ of the spermatozoa were associated with background clusters of five or more grains. Thus, for this study, spermatozoa with five or more grains were considered as labelled.

To determine the first appearance and the general excretion pattern of labelled spermatozoa in ejaculated semen, the longer exposed autoradiograms from five rabbits were evaluated. Using oil immersion $(\times 970)$, the number of grains/spermatozoon was counted for 500 randomly selected spermatozoa/ smear. Although individual grains were counted, cells were recorded as having $0,1,2,3,4,5$ to 9,10 to 19,20 to 29 , and 30 or more grains. For three rabbits, detailed grain counts were made on certain of the shorter exposure autoradiograms. In these latter studies, the actual number of grains was recorded for each of 100 spermatozoa having five or more grains. At the same time, any of the randomly selected spermatozoa appearing in the fields of view with 0 to 4 grains also were recorded. Thus, the total number of spermatozoa/sample evaluated for this phase of the study ranged from 157 to 1237. Even with the shorter exposure times of the autoradiographs used for these detailed counts, 
for two of the three rabbits the maximum grain count exceeded 100 grains/ spermatozoon; considerably above the level desirable for accurate counting.

\section{RESULTS}

The most advanced labelled germ cell type in specific stages of the cycle of the seminiferous epithelium (Swierstra \& Foote, 1963) was determined in autoradiograms from twenty-four testes. The observations for each of the ten time intervals were combined to arrive at a mean development phase for the most mature labelled germ cells at each time interval (Table 2). In tissues taken at $1 \mathrm{hr}$ or $4 \mathrm{hr}$ after injection, only spermatogonia and preleptotene primary spermatocytes were labelled. Thus, the most mature labelled germ cells seen at subsequent intervals had been preleptotene spermatocytes in early Stage I at the time of injection. Combined with published values for the relative frequency of the eight stages (Swierstra \& Foote, 1963), these data provided a series of

TABle 2

STAGE OF THE CYCLE OF THE SEMINIFEROUS EPITHELIUM CONTAINING THE MOST MATURE, LABELLED GERM GELLS

\begin{tabular}{c|c|c|c}
\hline $\begin{array}{c}\text { Time after } \\
\text { thymidine- } \\
\text { injection }\end{array}$ & $\begin{array}{c}\text { No. } \\
\text { testes }\end{array}$ & $\begin{array}{c}\text { Stage with most } \\
\text { mature, labelled } \\
\text { germ cells }\end{array}$ & No. cycles after injection \\
\hline $1.0 \mathrm{hr}$ & 1 & I & 0.00 \\
$4 \cdot 0 \mathrm{hr}$ & 2 & I & 0.02 \\
$6 \cdot 4 \mathrm{days}$ & 2 & II & 0.62 \\
$10 \cdot 0$ days & 2 & II & 0.95 \\
$24 \cdot 1$ days & 2 & III & 2.22 \\
$28 \cdot 0$ days & 2 & VI & 2.40 \\
$29 \cdot 0$ days & 3 & VII & 2.65 \\
$30 \cdot 0$ days & 3 & VII & 2.74 \\
31.0 days & 3 & VIII & 2.83 \\
32.0 days & 4 & \\
\hline
\end{tabular}

thirty-six estimates each representing the duration in days for a portion of one or more cycles of the seminiferous epithelium. Seven of these intervals were only 1 or 2 days in length and, since the uncertainty associated with a given stage of the cycle would be greatly magnified, they were excluded. From the remaining twenty-nine intervals, it was calculated that the mean ( \pm s.E.) duration of one cycle of the seminiferous epithelium was $10.7 \pm 0.5$ days. The portion of spermatogenesis from preleptotene spermatocytes until release of the resulting spermatozoa from the seminiferous tubule lumen requires about 2.92 cycles. Thus, labelled spermatozoa should be liberated into the caput epididymidis approximately 31.4 days after thymidine- ${ }^{3} \mathrm{H}$ injection. This agreed with their observed entry on Day 32.

The time of entry of labelled spermatozoa into the caput epididymidis was based on examination of autoradiograms from sixteen epididymides (Table 3). The first labelled spermatozoa entered the caput epididymidis between Day 31 and Day 32 after injection. Since labelled spermatids were not present in Stage VIII tubules of testes taken on Day 31, the few intensely labelled cells observed in the corresponding capita epididymidum ( $\mathrm{K}-84-\mathrm{L}$ and $\mathrm{K}-83-\mathrm{R})$ probably were prematurely sloughed Stage VII spermatids. With the methods used it was 
impossible to distinguish between late spermatids and spermatozoa. Comparison of the paired capita epididymidum from $\mathrm{k}-60$ or $\mathrm{k}-85$ shows that the percentage of labelled spermatozoa in the proximal caput epididymidis may vary even within a single rabbit.

From these data and those from testicular autoradiographs, it can be concluded that about 31.4 days are required for the last 2.9 of the 4.0 to 4.5 cycles of the seminiferous epithelium which constitute spermatogenesis including spermatogonia renewal (Heller \& Clermont, 1963). Thus 31.4 days is not the duration of spermatogenesis. Primary spermatocytes are formed in late Stage

TABLE 3

APPEARANCE OF THYMIDINE- ${ }^{3}$ H LABELLED SPERMATOZOA IN THE CAPUT EPIDIDYMIDIS OF RABBITS EJACULATED TWICE EVERY SECOND DAY

\begin{tabular}{|c|c|c|c|c|c|c|c|c|}
\hline \multirow{2}{*}{$\begin{array}{l}\text { Days } \\
\text { post- } \\
\text { injection }\end{array}$} & \multirow{2}{*}{$\begin{array}{l}\text { Rabbit } \\
\text { and } \\
\text { side }\end{array}$} & \multicolumn{2}{|c|}{$\begin{array}{l}\text { Labelled } \\
\text { spermatozoa }(\%)\end{array}$} & \multicolumn{4}{|c|}{ Gross incidence labelled spermatozoa } & \multirow{2}{*}{$\begin{array}{l}\text { Most mature, labelled } \\
\text { spermatids found in } \\
\text { seminiferous tubules at }\end{array}$} \\
\hline & & $\begin{array}{l}\text { Efferent } \\
\text { ducts }\end{array}$ & $\begin{array}{l}\text { Region } 2 \\
\text { of epidi- } \\
\text { dymis* }\end{array}$ & Region 3 & Region 4 & Region 5 & Region 6 & \\
\hline 28 & $\begin{array}{l}K-63-\mathrm{L} \\
\mathrm{K}-67-\mathrm{L}\end{array}$ & $\begin{array}{l}0 \cdot 0 \\
0.0\end{array}$ & $\begin{array}{l}0 \cdot 0 \\
0 \cdot 0\end{array}$ & - & - & - & - & $\begin{array}{l}\text { Stage III } \\
\text { Early Stage IV }\end{array}$ \\
\hline 29 & $\begin{array}{l}\mathrm{K}-66-\mathrm{R} \\
\mathrm{K}-70-\mathrm{R} \\
\mathrm{K}-75-\mathrm{R}\end{array}$ & $\begin{array}{l}0 \cdot 0 \dagger \\
0 \cdot 0 \\
0 \cdot 0\end{array}$ & $\begin{array}{l}0 \cdot 0 \\
0 \cdot 0 \\
0 \cdot 0\end{array}$ & - & E & E & $\overline{-}$ & $\begin{array}{l}\text { Late Stage VI } \\
\text { Late Stage VI } \\
\text { Late Stage IV }\end{array}$ \\
\hline 30 & $\begin{array}{l}\text { K-72-R } \\
\text { K-63-R } \\
\text { K-66-L }\end{array}$ & $\begin{array}{l}\text { No sper } \\
0 \cdot 0 \\
0.0\end{array}$ & $\begin{array}{c}\text { n. in epid } \\
0.0 \\
0.0\end{array}$ & dymis, at & $\begin{array}{l}\text { normal te } \\
\quad-\end{array}$ & $\begin{array}{c}\text { stis with } \mathrm{s} \\
-\end{array}$ & $\begin{array}{c}\text { permatog } \\
-\end{array}$ & $\begin{array}{l}\text { nic arrest } \\
\text { Early Stage VII } \\
\text { Stage VII }\end{array}$ \\
\hline 31 & $\begin{array}{l}\mathrm{K}-75-\mathrm{L} \\
\mathrm{K}-84-\mathrm{L} \\
\mathrm{K}-83-\mathrm{R}\end{array}$ & $\begin{array}{l}0 \cdot 0 \\
0 \cdot 0 \\
1 \cdot 2\end{array}$ & $\begin{array}{l}0 \cdot 0 \\
0 \cdot 3 \\
0 \cdot 8\end{array}$ & $\bar{z}$ & E & E & E & $\begin{array}{l}\text { Stage VII } \\
\text { Stage VII } \\
\text { Stage VII }\end{array}$ \\
\hline 32 & $\begin{array}{l}K-83-L \\
K-85-R \\
K-60-R \\
K-60-L\end{array}$ & $\begin{array}{r}7 \cdot 2 \\
28 \cdot 7 \\
22 \cdot 8 \\
50 \cdot 9\end{array}$ & $\begin{array}{r}5 \cdot 0 \\
20 \cdot 7 \\
20 \cdot 6 \\
51 \cdot 4\end{array}$ & $\begin{array}{c}+ \\
+ \\
++ \\
++\end{array}$ & $\begin{array}{l} \pm \\
\pm \\
+ \\
+\end{array}$ & $\begin{array}{l}\overline{-} \\
\pm\end{array}$ & $\begin{array}{l}\overline{-} \\
\overline{-}\end{array}$ & $\begin{array}{l}\text { Stage VIII } \\
\text { Stage VIII } \\
\text { Stage VIII } \\
\text { Stage VIII }\end{array}$ \\
\hline 33 & $\mathrm{~K}-85-\mathrm{L}$ & $4 \cdot 4$ & $2 \cdot 2$ & + & - & - & - & Stage VIII \\
\hline
\end{tabular}

* Regions of caput epididymidis as described by Nicander (1958).

† One tubule was observed which had about fifteen labelled spermatozoa grouped together. In this particular area of the section the tissue was folded over. Although labelled spermatozoa may have resulted from premature sloughing of spermatids from the germinal epithelium, they did not appear to be labelled as a result of artifacts.

VIII, but they incorporate thymidine into DNA as late as early Stage I. Developing germ cells remain as primary spermatocytes for $16 \cdot 1$ days or $15 \cdot 1$ days after thymidine-3 ${ }^{3} \mathrm{H}$ labelling, secondary spermatocytes for 1.2 days and spermatids for $15 \cdot 1$ days. The time required for spermatogonia renewal and multiplication also must be considered in calculating the duration of spermatogenesis. Although the exact pattern of spermatogonia renewal, and hence its relative duration, is unknown, these phases probably require 1.0 to 1.5 cycles. If spermatogonia multiplication and renewal require 11 to 16 days, the total duration of spermatogenesis in the rabbit lies between 42 and 47 days. 
Spermatozoan ${ }^{3} \mathrm{H}$-activity as determined by scintillation counting (Table 4) indicated that labelled spermatozoa first appeared in ejaculated semen on Days 38 to 43 post-injection. The sensitivity threshold for scintillation counting could prohibit detecting a low percentage of labelled spermatozoa. In fact, for $\mathrm{k}-70$ and $\mathrm{k}-64$, intensely labelled spermatozoa were observed in autoradiograms from Days 39 and 41, respectively.

Although the influence of fluctuations in and the level of the output of spermatozoa on epididymal transit and the excretion pattern of spermatozoa is largely unknown, they probably are important. The unilaterally castrated rabbits к-72, к-70, and к-67 had lower output values than the intact rabbits $\mathrm{k}-64$ and

TABLE 4

${ }^{3}$ H-AGTIVITY OF FOUR TIMES WASHED EJAGULATED SPERMATOZOA

(D.P.M./106 SPERMATOZOA)

\begin{tabular}{|c|c|c|c|c|c|}
\hline Days after injection & $\mathrm{k}-56$ & к-72 & $\mathrm{k}-70$ & $\mathrm{~K}-64$ & $\mathrm{k}-67$ \\
\hline $\begin{array}{l}\text { Injected dose } \\
\text { thymidine- }{ }^{3} \mathrm{H}(\mathrm{mc} / \mathrm{kg})\end{array}$ & —* & $0 \cdot 5$ & $1 \cdot 0$ & $1 \cdot 5$ & $1 \cdot 5$ \\
\hline Collection days & Variable & Even & Odd & Odd & Even \\
\hline $\begin{array}{l}34 / 35 \\
36 / 37 \\
38 / 39 \\
40 / 41 \\
42 / 43 \\
44 / 45 \\
46 / 47 \\
48 / 49 \\
50 / 51 \\
52 / 53 \\
54 / 55\end{array}$ & $\begin{array}{r}0 \\
3 \\
517 \\
1196 \\
\\
1759 \\
\\
391\end{array}$ & $\begin{array}{c}0 \\
0 \\
73 \\
130 \\
120 \\
91 \\
-\ddagger \\
34 \\
27 \\
19\end{array}$ & $\begin{array}{c}0 \\
97 \dagger \\
0 \\
175 \\
298 \\
424 \\
--\ddagger \\
-\ddagger \\
233 \\
3 \\
1\end{array}$ & $\begin{array}{r}17 \dagger \\
249 \dagger \\
2 \dagger \\
0 \\
1233 \\
1757 \\
3998 \\
2222 \\
1512\end{array}$ & $\begin{array}{r}1 \dagger \\
2 \dagger \\
23 \dagger \\
0 \\
388 \\
441 \\
1049 \\
1908 \\
518 \\
280 \\
110\end{array}$ \\
\hline
\end{tabular}

* Not administered i.v.; $0.5 \mathrm{mc}$ injected into each cavum vaginale. Two successive ejaculates collected on Days 29, 41, 43, 45, 48 and 52 .

† Values are considered to be artifacts and equal to zero. Autoradiograms of these samples did not contain intensively labelled spermatozoa.

$\ddagger$ Data lost through technical trouble.

K-82. Output $\left(\times 10^{6}\right) /$ two ejaculates after Day 30 or after unilateral castration was $60 \pm 8,38 \pm 7,18 \pm 4,150 \pm 18$ and $175 \pm 16$ for the five rabbits, respectively.

The general excretion pattern of labelled spermatozoa in ejaculated semen was established from autoradiographic data for five rabbits. Typical data are shown in Table 5. It was obvious that the first labelled spermatozoa are intensely radioactive. Subsequently a higher percentage was labelled, but the ${ }^{3} \mathrm{H}$-activity of individual labelled spermatozoa was lower. Small percentages of intensely labelled spermatozoa ( $>29$ grains/spermatozoon) were found for Days 39,41 and 42 for $\mathrm{K}-70(0 \cdot 2 \%)$, к-64 $(0 \cdot 6 \%)$, and к-67 $(2 \cdot 0 \%)$, respectively. When deemed advisable, 4000 spermatozoa/sample were evaluated to establish the first ejaculate containing labelled spermatozoa. Although most of the labelled spermatozoa were ejaculated during a period of about 2 weeks, excretion of weakly labelled spermatozoa ( 5 to 19 grains/spermatozoon) 
TABLE 5

EXGRETION OF LABELLED SPERMATOZOA IN SEMEN EJAGULATED BY RABBIT K-72 AS DETERMINED BY AUTORADIOGRAPHY (PERGENTAGE OF SPERMATOZOA WITH INDICATED NUMBER OF GRAINS AFTER 45 DAYS EXPOSURE)

\begin{tabular}{|c|c|c|c|c|c|c|c|c|c|c|}
\hline \multirow{2}{*}{$\begin{array}{c}\text { Davs } \\
\text { post- } \\
\text { injection }\end{array}$} & \multirow{2}{*}{$\begin{array}{c}\text { Total sperm. } \\
\text { in two ejaculates } \\
\left(\times 10^{6}\right)\end{array}$} & \multicolumn{9}{|c|}{ No. grains/sperm. } \\
\hline & & 0 & 1 & 2 & 3 & 4 & $5-9$ & $10-19$ & $20-29$ & $>29$ \\
\hline $\begin{array}{l}32 \\
34 \\
36 \\
38 \\
40 \\
42 \\
44 \\
46 \\
48 \\
50 \\
52 \\
54 \\
56 \\
58 \\
60 \\
62\end{array}$ & $\begin{array}{r}71 \\
71 \\
34 \\
73 \\
55 \\
50 \\
43 \\
16 \\
74 \\
42 \\
39 \\
124 \\
56 \\
120 \\
30 \\
2\end{array}$ & $\begin{array}{l}77 \\
76 \\
77 \\
65 \\
40 \\
23 \\
20 \\
26 \\
35 \\
52 \\
64 \\
66 \\
65 \\
74 \\
68 \\
68\end{array}$ & $\begin{array}{r}9 \\
11 \\
11 \\
10 \\
7 \\
9 \\
9 \\
8 \\
11 \\
12 \\
15 \\
12 \\
11 \\
9 \\
12 \\
12\end{array}$ & $\begin{array}{r}7 \\
8 \\
6 \\
5 \\
5 \\
6 \\
6 \\
9 \\
9 \\
10 \\
7 \\
9 \\
10 \\
8 \\
11 \\
10\end{array}$ & $\begin{array}{l}3 \\
3 \\
3 \\
2 \\
4 \\
5 \\
8 \\
8 \\
8 \\
8 \\
5 \\
6 \\
7 \\
4 \\
4 \\
6\end{array}$ & $\begin{array}{l}2 \\
1 \\
2 \\
1 \\
3 \\
3 \\
5 \\
7 \\
5 \\
5 \\
3 \\
3 \\
3 \\
1 \\
2 \\
2\end{array}$ & $\begin{array}{r}2 \\
1 \\
2 \\
2 \\
5 \\
11 \\
11 \\
21 \\
18 \\
11 \\
4 \\
4 \\
5 \\
2 \\
3 \\
2\end{array}$ & $\begin{array}{r}0 \\
0 \\
0 \\
1 \\
4 \\
9 \\
16 \\
15 \\
10 \\
2 \\
2 \\
0 \\
0 \\
0 \\
0 \\
0\end{array}$ & $\begin{array}{r}0 \\
0 \\
0 \\
1 \\
6 \\
14 \\
14 \\
4 \\
2 \\
1 \\
0 \\
0 \\
0 \\
0 \\
0 \\
0\end{array}$ & $\begin{array}{r}0 \\
0 \\
0 \\
13 \\
27 \\
20 \\
11 \\
2 \\
1 \\
0 \\
0 \\
0 \\
0 \\
0 \\
0 \\
0\end{array}$ \\
\hline
\end{tabular}

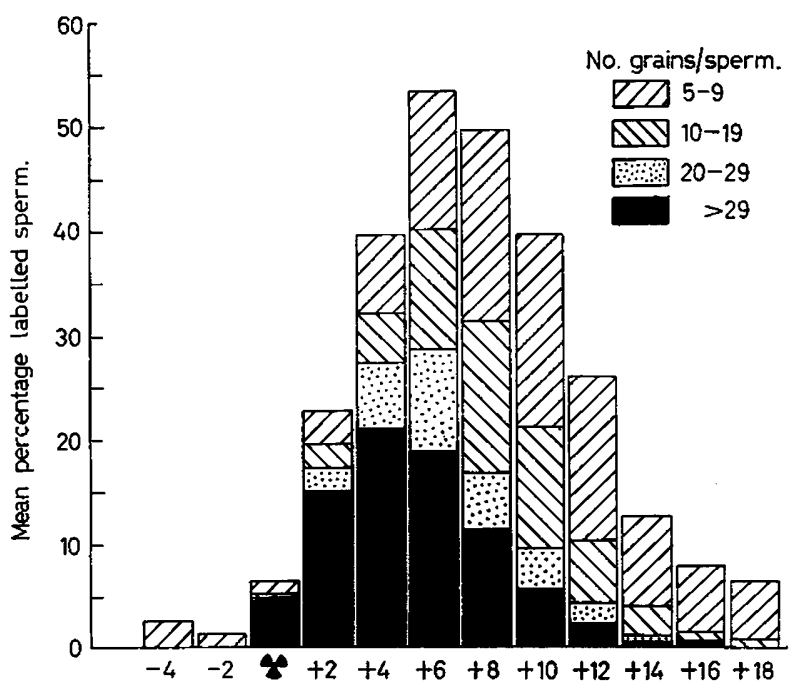

Days before and after appearance of first labelled sperm.

Text-Fig. 1. Mean excretion pattern of labelled spermatozoa after injection of thymidine${ }^{3} \mathrm{H}$. Mean for five rabbits centred on the first day after injection when ejaculated semen contained labelled spermatozoa.

continued for as long as 26 days (the last samples evaluated) for rabbits injected with $1.5 \mathrm{mc} / \mathrm{kg}$. Activity in these latter samples was not detectable by scintillation counting. Occasionally, an intensely labelled spermatozoon was detected as much as 2 to 3 weeks after initial excretion of labelled spermatozoa. The mean excretion pattern for five rabbits is shown in Text-fig. 1. Because of 
TABLE 6

THE EXCRETION PATTERN OF LABELLED SPERMATOZOA IN SEMEN EJACULATE BY RABBIT K-64 AS DETERMINED BY AUTORADIOGRAPHY (\% SPERM. WITH INDICATED NO. GRAINS AFTER 14 DAYS EXPOSURE)

\begin{tabular}{c|c|c|c|c|c|c|c|c|c|c|c|c}
\hline $\begin{array}{c}\text { Days } \\
\text { post- } \\
\text { injection }\end{array}$ & \multicolumn{10}{|c|}{ No. grains/sperm. } \\
\cline { 2 - 13 } & 0 & 1 & 2 & 3 & 4 & $5-19$ & $20-34$ & $35-49$ & $50-64$ & $65-79$ & $80-94$ & $>94$ \\
\hline 39 & 77 & 8 & 7 & 4 & 2 & 2 & 0 & 0 & 0 & 0 & 0 & 0 \\
41 & 77 & 9 & 6 & 3 & 2 & 2 & 0 & 0 & 0 & 0 & 0 & 1 \\
43 & 66 & 13 & 5 & 3 & 2 & 2 & 1 & 1 & 2 & 3 & 2 & 0 \\
45 & 52 & 7 & 6 & 4 & 3 & 8 & 3 & 5 & 3 & 5 & 3 & 0 \\
47 & 36 & 7 & 5 & 4 & 4 & 17 & 5 & 8 & 7 & 4 & 2 & 0 \\
49 & 26 & 7 & 6 & 6 & 3 & 23 & 11 & 10 & 7 & 3 & 0 & 0 \\
51 & 23 & 9 & 6 & 6 & 5 & 30 & 9 & 10 & 2 & 1 & 0 & 0 \\
53 & 27 & 10 & 9 & 7 & 4 & 35 & 4 & 3 & 1 & 0 & 0 & 0 \\
\hline
\end{tabular}

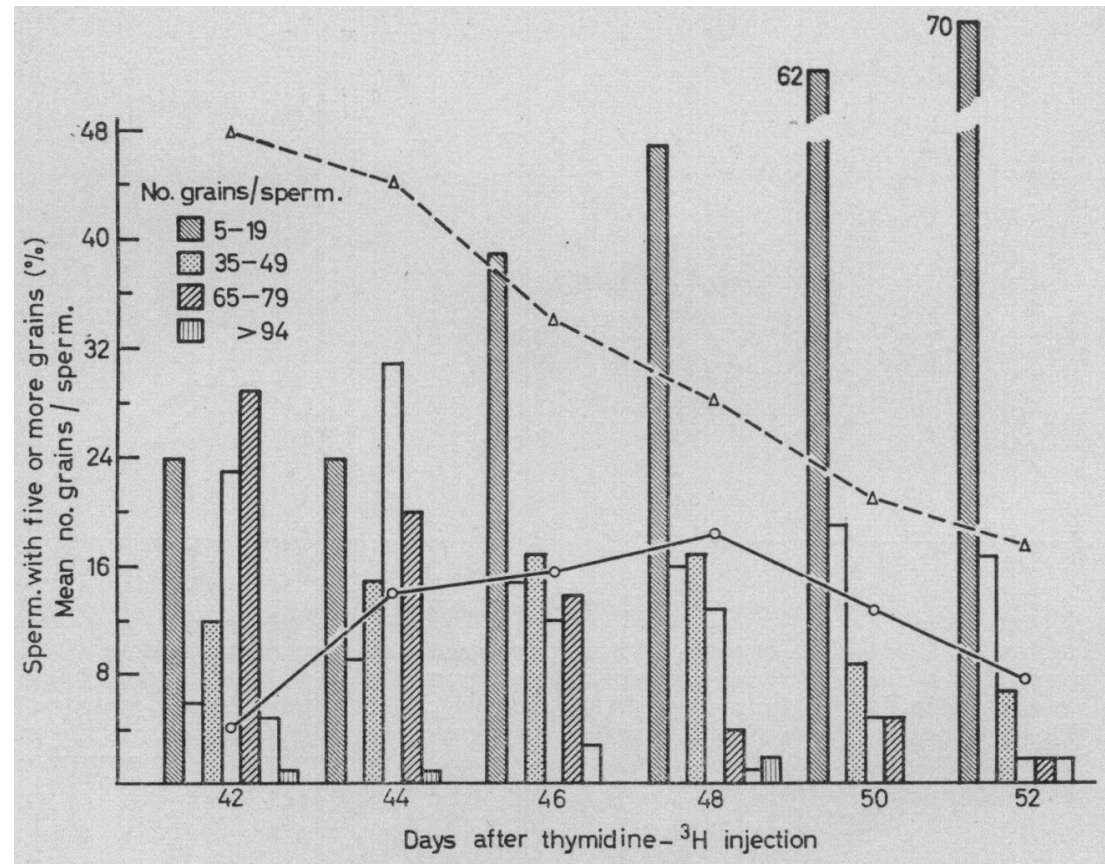

TEXT-FIG. 2. Histograph showing the excretion pattern of labelled spermatozoa for $\mathrm{K}-82$ (treated with $1.5 \mathrm{mc} / \mathrm{kg}, 14$ days exposure) expressed as percentages of the spermatozoa with five or more grains each. Open bars represent 20 to 34,50 to 64 and 80 to 94 grains/ spermatozoon. The line graphs show: $O$, mean number of grains/spermatozoon for all spermatozoa, and $\Delta$, mean number of grains/spermatozoon for spermatozoa with five or more grains.

the differences in injected dosage and autoradiograph exposure time, the figure represents only the general pattern of labelling.

Since the results suggested that the number of grains/labelled spermatozoon was a function of time after injection and differed from a normal distribution, more detailed grain counts were made on shorter exposure autoradiograms for three rabbits. These data, as illustrated in Table 6 , confirmed those presented 
above; a higher percentage of tritiated spermatozoa are heavily labelled in early samples than in subsequent ones. For example, in pooled ejaculates collected from $\mathrm{k}-82$ (Text-fig. 2), $58 \%$ of the labelled spermatozoa (spermatozoa with five or more grains) on Day 42 had fifty or more grains each, while on Days 46 and 50 only $29 \%$ and $10 \%$ of the labelled spermatozoa were labelled as heavily. Simultaneously, however, the total incidence of labelled spermatozoa increased from $8 \%$ to $44 \%$ and to $58 \%$ on Days 42,46 and 50 , respectively. This excretion pattern largely reflects the different germ cell types into which thymidine- ${ }^{3} \mathbf{H}$ was initially incorporated.

Text-fig. 2 also shows the mean numbers of grains/spermatozoon calculated on the basis of all spermatozoa and of labelled spermatozoa only. Largely as a

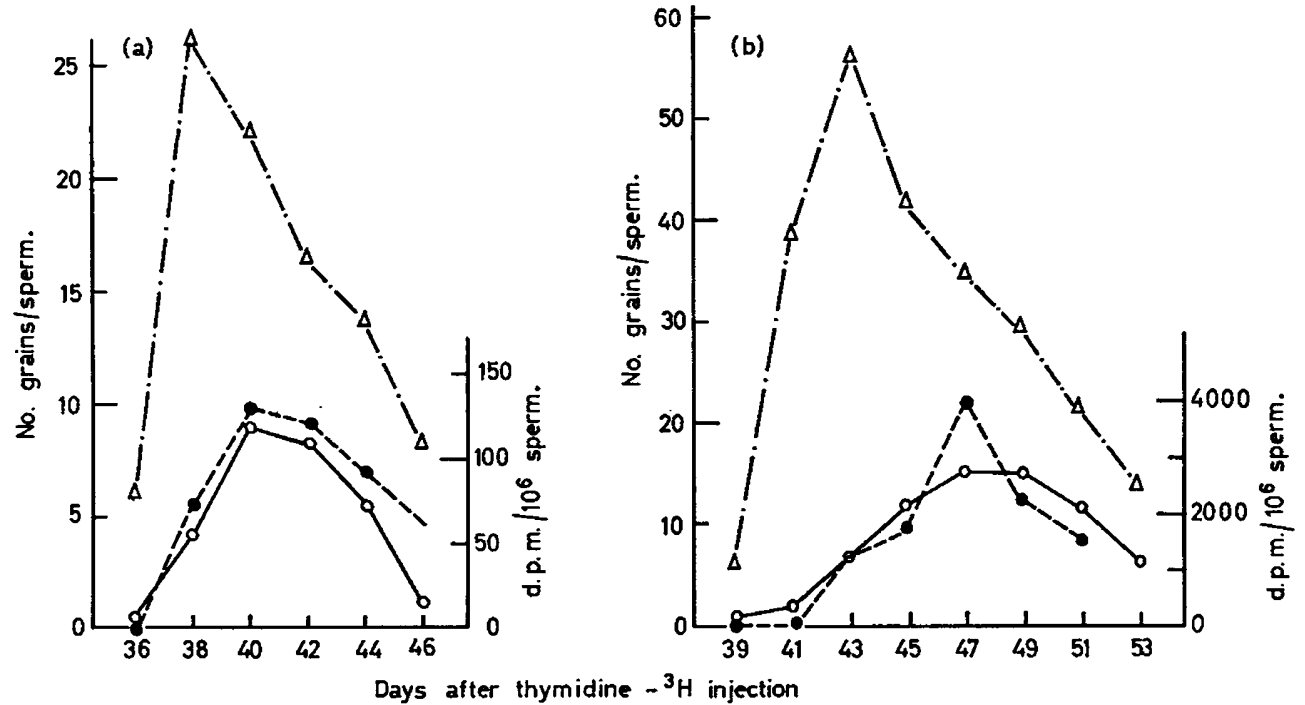

Text-Fig. 3. Comparison between ${ }^{3} \mathrm{H}$-activity of ejaculated spermatozoa as determined by scintillation counts and grain counts of autoradiograms for (a) $\mathrm{k}-72(0.5 \mathrm{mc} / \mathrm{kg}, 22$ days exposure), and (b) $\mathrm{k}-64(1.5 \mathrm{mc} / \mathrm{kg}, 14$ days exposure). scintillation counts as d.p.m./ $10^{6}$ spermatozoa; $O$, mean number of grains/spermatozoon for all spermatozoa; $\Delta$, mean number of grains/spermatozoon for spermatozoa with five or more grains. Grains present over spermatozoa in samples from $\mathrm{k}-72$ on Day 36 and $\mathrm{k}-64$ on Day 39 represent background.

result of an increased percentage of labelled cells, the overall mean number of grains/spermatozoon gradually increased, peaked and subsequently declined. This curve represents mean activity/cell and should resemble that obtained by scintillation counting. The mean number of grains/labelled spermatozoon, however, decreased steadily after initial ejaculation of labelled spermatozoa. Thus, since the labelling pattern was not similar on successive days and did not follow a normal distribution curve, the overall ${ }^{3} \mathrm{H}$-activity of the sample can be very misleading. This is illustrated in Text-fig. 3 where the overall ${ }^{3} \mathrm{H}$-activity/spermatozoon, as determined by grain counts on autoradiograms or by scintillation counting, is compared with the degree of labelling of spermatozoa with five or more grains. The activity calculated from grain counts was in good agreement with that determined by scintillation counting, but both 
curves peaked later than that representing the mean activity of labelled spermatozoa. The autoradiographic method also gave greater sensitivity.

The duration of epididymal transit during an extended period of uniform collection of two ejaculates every second day was inferred from the difference between the time of entry of labelled spermatozoa into the proximal caput epididymidis and their appearance in ejaculated semen. The results showed that the labelled spermatozoa first entered the proximal caput epididymidis 31.4 days after injection. For five rabbits, labelled spermatozoa were first detected in ejaculated semen on Days 38, 39, 41, 42 and 42. Thus, the apparent duration of epididymal transit ranged from 6.6 to 10.6 days with a mean of $9 \cdot 0$ days. Autoradiographic data for K-72 and K-82 suggested that labelled spermatozoa may have been available for ejaculation 1 day prior to the time

TABLE 7

THE BIOLOGICAL HALF-LIFE OF ${ }^{3}$ H-WATER IN BLOOD AND SEMINAL PLASMA

\begin{tabular}{c|l|r|r|c|c}
\hline Rabbit & Plasma & $\mathcal{N}$ & $b^{*}$ & $\pm S_{b}$ & $\begin{array}{c}\text { Biological half-life } \\
(\text { days } \pm \text { s.D. })\end{array}$ \\
\hline \multirow{2}{*}{ K-64 } & Blood & 21 & -0.0634 & 0.0010 & $4.75 \pm 0.08$ \\
& Semen & 16 & -0.0642 & 0.0013 & $4.69 \pm 0.09$ \\
K-60 & Blood & 18 & -0.0396 & 0.0013 & $7.60 \pm 0.25$ \\
& Semen & 6 & -0.0398 & 0.0019 & $7.54 \pm 0.36$ \\
K-71 & Blood & 14 & -0.0505 & 0.0011 & $5.96 \pm 0.13$ \\
& Semen & 6 & -0.0548 & 0.0014 & $5.49 \pm 0.14$ \\
K-72 & Semen & 18 & -0.0647 & 0.0014 & $4.65 \pm 0.10$ \\
K-70 & Semen & 8 & -0.0558 & 0.0044 & $5.39 \pm 0.42$ \\
\hline
\end{tabular}

* Sample regression coefficient as (log d.p.m.)/day.

they actually were collected; more than twenty-nine grains were associated with $13 \%$ and $7 \%$ of the spermatozoa in the first samples containing labelled spermatozoa.

The biological half-life of ${ }^{3} \mathrm{H}$ circulating in the body water compartment was calculated from assays of blood and seminal plasma samples taken 1 to 47 days after injection (Table 7). All rabbits had free access to water. Although hydrolysed plasma samples were used, preliminary tests with plasma distillates showed that all of the ${ }^{3} \mathrm{H}$-activity present in the plasma samples was in the form of ${ }^{3} \mathrm{H}$-water. The mean biological half-life for ${ }^{3} \mathrm{H}$-water in the five rabbits was $5 \cdot 61$ days.

\section{DISCUSSION}

Within 60 min of injection, thymidine- ${ }^{3} \mathrm{H}$ is degraded into metabolites incapable of being incorporated into DNA (Rubini et al., 1960; Monesi, 1962). Thus only cells, such as preleptotene spermatocytes, which are incorporating thymidine into DNA during this short period of availability should become labelled. However, not all cells of apparently the same developmental phase will be labelled. About one-half of the Stage I preleptotene spermatocytes were 
labelled $1 \mathrm{hr}$ after injection and, as a consequence, neither all Stage VIII spermatids nor all spermatozoa in the efferent ducts on Days 32 and 33 were labelled.

The maximum percentage of ${ }^{3} \mathrm{H}$-labelled spermatozoa in ejaculated semen ranged from $51 \%$ to $64 \%$, but was much lower than reported by Sirlin \& Edwards (1958) for mouse spermatozoa ejaculated after adenine-8 ${ }^{14} \mathrm{C}$ injection. In autoradiographic studies they obtained the first labelled spermatozoa about 30 days after injection after which time the percentage of labelled cells increased rapidly and reached a maximum of about $90 \%$ near Day 38 . The trend was similar to that reported herein, but the maximum percentage of mouse spermatozoa labelled by adenine-8-14 $\mathrm{C}$ was much higher.

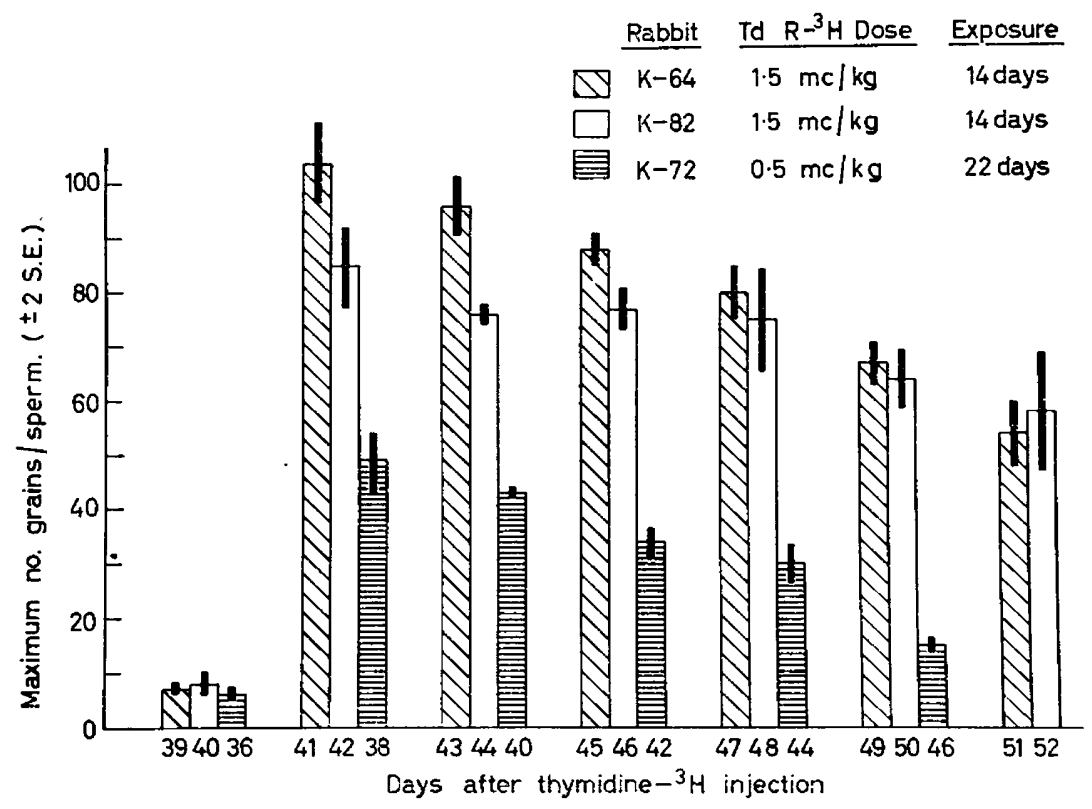

Text-Fig. 4. Mean maximum number of grains/spermatozoon in autoradiograms of ejaculated semen. Mean for the ten most heavily labelled spermatozoa out of 157 to 1237 spermatozoa evaluated for each sample.

Sirlin \& Edwards (1958) also reported that the maximum number of grains/ spermatozoon followed a curve similar to that for the percentage of labelled spermatozoa and increased from about 20 grains/spermatozoon on Day 30 to 35 grains/spermatozoon on Day 38 and subsequently declined. In the present study, the maximum number of grains/spermatozoon decreased after the first ejaculate containing labelled spermatozoa (Text-fig. 4). One reason for this and other discrepancies between the two reports is the different precursor used. Adenine-8 $-14 \mathrm{C}$ probably is degraded at a considerably slower rate than thymidine-methyl $-{ }^{3} \mathrm{H}$ and, hence, is available for incorporation several days after injection (Sirlin, 1958). This is similar to the situation after ${ }^{32} \mathrm{P}$ injection. With continued availability, tracer is incorporated two or more times into the same nuclear material; the daughter preleptotene spermatocytes of previously labelled B-spermatogonia incorporate additional labelled precursor. Thus, the 
maximum activity/labelled spermatozoon follows by several days the first appearance of labelled spermatozoa (also see discussion by Sirlin \& Edwards, 1958). After thymidine- ${ }^{3} \mathrm{H}$ injection, 'repeat labelling' of a nucleus is negligible and maximum labelling of spermatozoa in the first radioactive samples results.

Theoretically, all spermatozoa which had incorporated thymidine- ${ }^{3} \mathrm{H}$ as preleptotene spermatocytes should have a similar number of grains while those which had incorporated thymidine- ${ }^{3} \mathrm{H}$ as $\mathrm{B}$-spermatogonia should have onehalf this number. The maximum difference in availability of thymidine- ${ }^{3} \mathrm{H}$ to DNA synthesizing germ cells would be about $60 \mathrm{~min}$ which, if the rate of incorporation and synthesis into DNA is uniform, would account for a variability of about $7 \%$ in the number of grains/cell of a given type. Thus, on the basis of

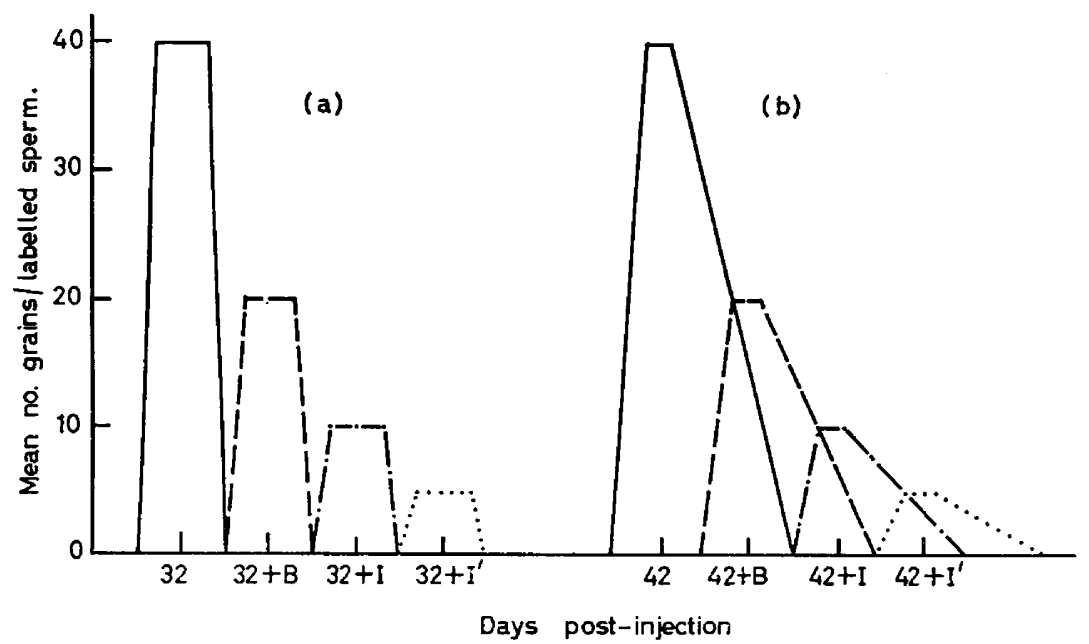

TExT-FIG. 5. Theoretical excretion pattern of labelled spermatozoa from the efferent ducts (a) and in ejaculated semen (b). Although it should be possible to distinguish by their grain count spermatozoa labelled as different precursor germ cells when they enter the efferent ducts (a), because of apparent mixing during epididymal transit and other limitations this multimodal distribution may not be resolved in ejaculated semen (b). The time required for B-, I-, and $I^{\prime}$-spermatogonia to form preleptotene spermatocytes is represented by $\mathrm{B}, \mathrm{I}$ and $\mathrm{I}^{\prime}$ on the $\mathrm{X}$-axis. Epididymal transit is depicted as taking 10 days.

grain counts it should be possible to distinguish spermatozoa which had been labelled with thymidine- ${ }^{3} \mathrm{H}$ as preleptotene spermatocytes from those which had been labelled as B- or In-spermatogonia. The mean grain count/labelled spermatozoon in each successive 'wave' of labelled cells should approximate one-half of that in the preceding one (Text-fig. 5). At least partially because of the ejaculation frequency used, resolving these 'waves' of labelled spermatozoa, representing descendants of primary spermatocytes and spermatogonia, in ejaculated semen was not possible in the present study. Limitations inherent in ARG, particularly with tritium (Levi, Rogers, Bentzon \& Nielsen, 1963; Sirlin \& Edwards, 1958) combined with the apparent mixing of spermatozoa during epididymal transit may preclude resolution of the multimodal distribution of grain count in a series of ejaculates. Examination of seminiferous tubules suggested that these 'waves' of progressively less active spermatozoa follow at intervals of 2 to 4 days. 
A number of brief communications have reported the time of first appearance of labelled spermatozoa in semen collected from a total of twelve rabbits after injection of various isotopes (Koefoed-Johnsen, 1958; Foote \& KoefoedJohnsen, 1959; Hupp et al., 1961; Yassen \& Foote, 1963). Regardless of the isotope used $\left({ }^{32} \mathrm{P}\right.$, adenine- $8{ }^{-14} \mathrm{C}$, or thymidine- $\left.{ }^{3} \mathrm{H}\right)$, except for the report by Hupp et al., the first spermatozoa with labelled DNA were detected in ejaculates collected between 38 and 42 days post-injection. Hupp et al. (1961) apparently obtained the first labelled spermatozoa from four rabbits between 42 and 48 days after injection. However, in none of these investigations was a uniform and intensive semen collection schedule followed. The importance of this procedure to minimize epididymal reserves of spermatozoa, fluctuations of these reserves, and epididymal transit time and to maximize output of spermatozoa can be deduced from investigations with bulls by Amann \& Almquist (1961, 1962).

The present data clearly show that the overall ${ }^{3} \mathrm{H}$-activity curve of spermatozoa from successive semen samples does not reflect accurately the excretion pattern of spermatozoa labelled as preleptotene spermatocytes or spermatogonia. Ejaculates having the highest ${ }^{3} \mathrm{H}$-activity generally have a high percentage of labelled spermatozoa, but follow by several days the peak excretion of spermatozoa labelled only as preleptotene spermatocytes. Thus, reports on the mean epididymal transit time of labelled spermatozoa based on GeigerMüller counts of DNA from ejaculated spermatozoa (Koefoed-Johnsen, 1958; Orgebin-Crist, 1962) in retrospect must be considered questionable. This is true even after correction for the level of circulating labelled DNA precursor. Essentially the only reliable information from such experiments is that on the initial appearance of labelled spermatozoa.

\section{ACKNOWLEDGMENTS}

This investigation was supported in part by U.S. Public Health Service postdoctoral fellowship GPD-1 7, 876 from the Division of General Medical Sciences, National Institutes of Health. The authors are indebted to Dr V. Middelboe, Department of Physics, The Royal Veterinary and Agricultural College, Copenhagen, for use of the scintillation counter. Actuary A. Nielsen, Institute of Human Genetics, University of Copenhagen, made valuable contributions in discussions of the quantitative interpretation of grain count data. The skilful technical assistance of Miss E. Frederiksen, Mrs L. Steen-Andersen, and Miss A. S. Berner is gratefully acknowledged.

\section{REFERENCES}

Amann, R. P. \& Almquist, J. O. (1961) Reproductive capacity of dairy bulls. V. Detection of testicular deficiencies and requirements for experimentally evaluating testis function from semen characteristics. F. Dairy Sci. 44, 2283.

Amann, R. P. \& Almouist, J. O. (1962) Reproductive capacity of dairy bulls. VI. Effect of unilateral vasectomy and ejaculation frequency on sperm reserves; aspects of epididymal physiology. 7. Reprod. Fertil. 3, 260.

Foote, R. H. (1959) The use of radioactive isotopes to study spermatogenesis and transport of spermatozoa in mammals. A review. Symp. Genet. 9, 1.

Foote, R. H. \& Koefoed-Johnsen, H. H. (1959) The use of adenine-8-C14 for studying spermatogenesis in the rabbit. (Abstr.) F. Anim. Sci. 18, 1553.

Heller, C. G. \& Glermont, Y. (1963) Spermatogenesis in man: an estimate of its duration. Science, 140,184 . 
Hupp, E. W., Austin, J. W. \& MurphreE, R. L. (1961) Radioisotope labelling of sperm in bulls and rabbits. (Abstr.) 7. Anim. Sci. 20, 973.

KOEFOED-JoHNSEN, H. H. (1958) Undersegelser over saeddannelsen (Investigations on sperm formation). Annual Report Sterility Research Institute, p. 18. The Royal Veterinary and Agricultural College, Copenhagen.

Levi, H., Rogers, A. W., Bentzon, M. W. \& Nielsen, A. (1963) On the quantitative evaluation of autoradiograms. Mat.-fys. Medd. 33, (11), 1.

MoNEsI, V. (1962) Autoradiographic study of DNA synthesis and the cell cycle in spermatogonia and spermatocytes of mouse testis using tritiated thymidine. F. Cell Biol. 14, 1.

NICANDER, L. (1958) On the regional histology and cytochemistry of the ductus epididymis in rabbits. Acta morph. neerl.-scand. 1, 99.

Orgebin-CRIST, M. C. (1962) Recherches expérimentales sur la durée de passage des spermatozoides dans l'épididyme du taureau. Annls. Biol. anim. Biochim. Biophys. 2, 51.

Ortavant, R. (1958) Le cycle spermatogénétique chez le bélier. D.Sc. thesis, University of Paris.

Rubini, J. R., Cronkite, E. P., Bond, V. P. \& Fliedner, T. M. (1960) The metabolism and fate of tritiated thymidine in man. F. clin. Invest. 39, 909.

SirLIn, J. L. (1958) The labelling of mouse spermatozoa by adenine-8-C14 and thymidine-H ${ }^{3}$. Exp. Cell Res. 15, 250.

Sirlin, J. L. \& Edwards, R. G. (1958) The labelling of mammalian spermatozoa with radioactive tracers. F. exp. Zool. 137, 363.

Swierstra, E. E. \& Foote, R. H. (1963) Cytology and kinetics of spermatogenesis in the rabbit. 7. Reprod. Fertil. 5, 309.

Yasseen, A. M. \& Foote, R. H. (1963) Autoradiography of rabbit sperm. (Abstr.). F. Anim. Sci. 22, 867. 